\title{
Cerebellar mutism following the posterior fossa tumour excision
}

\author{
Raghavendra Nayak, Girish Menon, Sanjeev Rathod
}

Neurosurgery, Kasturba Medical College, Manipal, Manipal Academy of Higher Education (MAHE), Manipal, Udupi, Karanataka, India

\section{Correspondence to}

Dr Raghavendra Nayak; drnayakneuro@gmail.com

Accepted 24 November 2020

Check for updates

(C) BMJ Publishing Group Limited 2020. No commercial re-use. See rights and permissions. Published by BMJ.

To cite: Nayak R, Menon G, Rathod S. BMJ Case Rep 2020;13:e239969. doi:10.1136/bcr-2020239969

\section{DESCRIPTION}

A 6-year-old child presented with a holocranial headache with vomiting for 1 month. On examination, the child had an ataxic gait with swaying towards left side and papilloedema. MRI brain showed a well-defined extra-axial altered signal intensity mass, measuring $4 \times 4.5 \times 4 \mathrm{~cm}$, which was hypointense on $\mathrm{T} 1$, heterogeneously hyperintense on T2 and fluid-attenuated inversion recovery. It appeared to be arising from the upper part of the vermis, occupying the whole fourth ventricle and causing compression and anterior displacement of the brainstem with the occlusion of the cerebral aqueduct causing obstructive hydrocephalus (figure 1). Our differentials were medulloblastoma, ependymoma or choroid plexus papilloma. We did a midline suboccipital craniotomy and through the telovelar approach, grossly excised the mass. The child was shifted to the intensive care unit with a plan to extubate on next morning. But he took time to regain consciousness and was extubated on second postoperative day morning. He was conscious, oriented and was talking on the day of extubation. The next day morning, he was conscious but

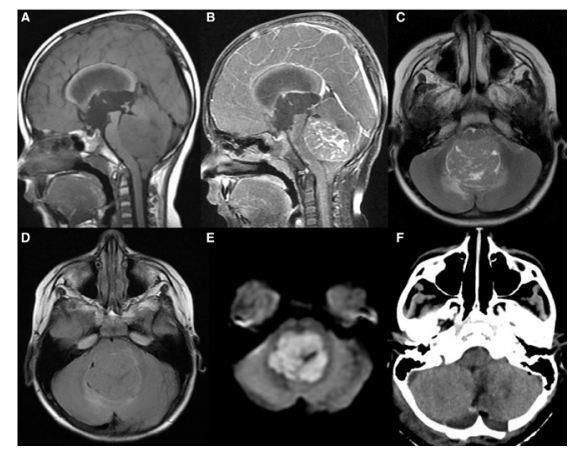

Figure 1 MRI brain showed a well-defined extra-axial altered signal intensity lesion, measuring $4 \times 4.5 \times 4 \mathrm{~cm}$, which was hypointense on T1 (A), heterogeneously enhancing on giving Gadolinium contrast (B), heterogeneously hyperintense with cystic areas within on $\mathrm{T} 2$ and fluid-attenuated inversion recovery $(C, D)$. Mass was showing restricted diffusion on diffusion-weighted imaging. It was appeared to arising from the upper part of the vermis, occupying the whole fourth ventricle and causing compression and anterior displacement of the brainstem with the occlusion of the cerebral aqueduct causing the obstructive hydrocephalus. Presence of mild cerebellar tonsillar herniation and tortuous optic nerves were indicating the raised intracranial tension. $\mathrm{CT}$ imaging was showing the gross total excision of the tumour without any postoperative haematoma (E).

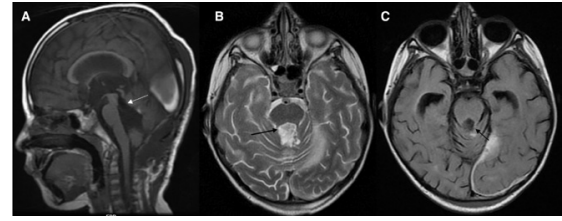

Figure 2 MRI brain showing injury to bilateral superior cerebellar peduncles (arrows).

was completely mute. He was unable to produce a single word; crying was the only answer for any attempt of speech. No sensory aphasia was noted as he was following our commands. $\mathrm{He}$ was apathetic, irritable and showed no interest in oral intake. He had profound truckle ataxia and hypotonia but there was no weakness in limbs. CT brain was done which was showing no postoperative site hematoma, infarct or worsening of hydrocephalus. The child was kept on Ryle's tube feeding and ambulated with the help of a physiotherapist. Speech and occupational therapy were started simultaneously. He began to eat and drink on sixth postoperative day.

Child was not able to produce any words for about initial 20 days. Then, he started with a single word which gradually progressed into sentences. Initially, the speech was very slow, monotonous and was associated with slurring. There was a lack of spontaneity and also difficulty in initiation of the speech. Speech slowly improved over of 2 months.

Cerebellar mutism syndrome (CMS) is a complex speech disorder which occurs in $8 \%-24 \%$ of cases of posterior fossa tumour excision. ${ }^{1}$ CMS as a complication posterior fossa surgery was first mentioned by Hirsch et $a l^{2}$ in 1979 but the detailed description of the CMS was given by Rekate et $a l^{3}$ in 1985. It is a complex constellation of neurological and neurocognitive abnormalities which includes ataxia, hypotonia, oropharyngeal dysfunction (dysphagia, dysarthria), pseudobulbar palsy, brain stem dysfunction including long tract signs and cranial neuropathies, urinary incontinence and cerebellar cognitive affective syndrome. ${ }^{4}$

Patay ${ }^{5}$ proposed the possible pathophysiological mechanism which states that dentatethalamocortical pathway serves as an integration centre between cerebral cortex and cerebellum. Damage to this white matter pathway along with damage to the bilateral dentate nuclei during tumour resection could result in CMS (figure 2).

Several predisposing factors for CMS have been observed by Gadgil et al. ${ }^{1}$ Medulloblastoma 
histology, midline tumour involving vermis, high fourth ventricle location and involvement of brain stem are considered as strong risk factors whereas large-sized tumour, younger age, preoperative language impairment, radical resection of the tumour and high vermian incisions were considered as possible risk factors. Except for preoperative language impairment, all risk factors are observed in our patient.

Treatment consists of intense involvement of multidisciplinary departments like physiotherapy, speech therapy and occupational therapy. Even after the treatment, permanent disabling sequelae in the form of dysarthria, ataxia, slow speech, emotional problems have been observed in $68 \%$ of cases. ${ }^{6}$ The duration of mutism varies from 4 days to 5 months (average 8 weeks). ${ }^{6}$

\section{Learning points}

Postoperative cerebellar mutism, although uncommon, should be expected more so in the presence of predisposing factors mentioned in the article.

- Patient and relatives should be properly counselled regarding this syndrome prior to the surgery.
Contributors RN: manuscript preparation and analysis. SR: data collection. GM: approval of draft.

Funding The authors have not declared a specific grant for this research from any funding agency in the public, commercial or not-for-profit sectors.

Competing interests None declared.

Patient consent for publication Parental/guardian consent obtained.

Provenance and peer review Not commissioned; externally peer reviewed.

\section{REFERENCES}

1 Gadgil N, Hansen D, Barry J, et al. Posterior fossa syndrome in children following tumor resection: knowledge update. Surg Neurol Int 2016;7:S179.

2 Hirsch JF, Renier D, Czernichow P, et al. Medulloblastoma in childhood. survival and functional results. Acta Neurochir 1979;48:1-15.

3 Rekate HL, Grubb RL, Aram DM, et al. Muteness of cerebellar origin. Arch Neurol 1985;42:697-8.

4 Gudrunardottir T, Morgan AT, Lux AL, et al. Consensus paper on post-operative pediatric cerebellar mutism syndrome: the Iceland Delphi results. Childs Nerv Syst 2016;32:1195-203.

5 Patay Z. Postoperative posterior fossa syndrome: unraveling the etiology and underlying pathophysiology by using magnetic resonance imaging. Childs Nerv Syst 2015;31:1853-8.

6 Gelabert-González M, Fernández-Villa J. Mutism after posterior fossa surgery. review of the literature. Clin Neurol Neurosurg 2001;103:111-4.

Copyright 2020 BMJ Publishing Group. All rights reserved. For permission to reuse any of this content visit

https://www.bmj.com/company/products-services/rights-and-licensing/permissions/

BMJ Case Report Fellows may re-use this article for personal use and teaching without any further permission.

Become a Fellow of BMJ Case Reports today and you can:

- Submit as many cases as you like

- Enjoy fast sympathetic peer review and rapid publication of accepted articles

- Access all the published articles

Re-use any of the published material for personal use and teaching without further permission

Customer Service

If you have any further queries about your subscription, please contact our customer services team on +44 (0) 2071111105 or via email at support@bmj.com.

Visit casereports.bmj.com for more articles like this and to become a Fellow 